\title{
HUBUNGAN PERILAKU HIDUP BERSIH DAN SEHAT DENGAN PENGETAHUAN DAN PERILAKU MENGGOSOK GIGI
}

\author{
Tita Kartika Dewi ${ }^{1)}$, Fanny Nurramdhani Syaefuddin ${ }^{2)}$ \\ Jurusan Keperawatan Gigi, Politeknik Kesehatan Tasikmalaya \\ email: itakartikadewi21@gmail.com
}

\begin{abstract}
Abstrak
Perilaku Hidup Bersih dan Sehat bertujuan untuk meningkatkan perilaku kesehatan yang dilakukan atas kesadaran sehingga keluarga dapat menolong dirinya sendiri di bidang kesehatan. Pengetahuan adalah salah satu yang dapat mempengaruhi kebersihan seseorang.. Tujuan dari penelitian ini untuk mengetahui hubungan Perilaku Hidup Bersih dan Sehat dengan pengetahuan dan perilaku menggosok gigi pada siswa kelas IV SDN Sukamanah 2 Kota Tasikmalaya. Metode Penelitian menggunakan metode non eksperimental dengan rancangan cross sectional menggunakan sampel sebesar 42 siswa. Cara pengukuran menggunakan kuesioner tingkat pengetahuan Perilaku Hidup Bersih dan Sehat yang sudah diterapkan di sekolah, pengetahuan menggosok gigi, observasi lembar cheklist untuk mengetahui perilaku menggosok gigi. Hasil Penelitian menggunakan analisis data uji spearman di dapatkan nilai pada pengetahuan menggosok gigi p value 0,000 <0,05 yang menunjukkan hubungan antara Perilaku Hidup Bersih dan Sehat dengan pengetahuan menggosok gigi. Sedangkan pada perilaku menggosok gigi di dapatkan nilai p value 0,002 < 0,05 hubungan antara Perilaku Hidup Bersih dan Sehat dengan Perilaku menggosok gigi. Kesimpulan penelitian adalah sekolah yang telah menerapkan Perilaku Hidup bersih dan Sehat berpengaruh terhadap pengetahuan dan perilaku menggosok gigi..
\end{abstract}

Kata kunci : perilaku hidup bersih dan sehat, pengetahuan, perilaku menggosok gigi

\begin{abstract}
Clean and Healthy Behavior aims to improve health behavior that leads the family can help themselves in the health sector. Knowledge is one that can affect one's cleanliness. The purpose of this study was to determine the relationship between Clean and Healthy Behavior with the knowledge and behavior of brushing teeth in IV students of SDN Sukamanah 2 Tasikmalaya City. The method of this study used a non-experimental method with cross sectional design by using 42 students as samples. The instrument used questionnaire which consists of some questions about knowledge level about Clean and Healthy Life Behavior that has been applied at school as well as knowledge about brushing teeth and also observing checklist form to know the behavior of brushing teeth.The results of the study which used spearman test data analysis got $p$ value 0,000 $<0.05$ on the knowledge of brushing teeth and p value $0.002<0.05$ or tooth brushing behavior. It showed a correlation between Healthy Life Behavior and Healthy with knowledge of brushing teeth and brushing teeth behavior. The conclusion of this study was that the school which had implemented clean and healthy behavior influenced the students' knowledge and behavior of brushing teeth.
\end{abstract}

Keywords: clean and healthy life behavior, knowledge, tooth brushing behavior

\section{PENDAHULUAN}

Menurut World Health Organization (WHO) sehat adalah suatu keadaan sejahtera yang meliputi fisik, mental dan sosial yang tidak hanya bebas dari penyakit atau kecacatan, kondisi sehat yang dirasakan dapat membuat individu menjalani kehidupannya dengan baik. Dalam pencapaian pada kondisi yang sehat, individu juga perlu untuk berperilaku sehat. Perilaku sehat merupakan tindakan yang dilakukan baik secara langsung atau tidak langsung, untuk mempertahankan dan meningkatkan kesehatannya serta mencegah dari risiko penyakit. Perilaku sehat dapat diwujudkan dengan memperoleh gizi yang sesuai dengan kebutuhan, melakukan olahraga secara rutin, memiliki waktu istirahat dan tidur yang cukup, menjaga kebersihan diri 
dan lingkungan serta melakukan perawatan gigi dan mulut. Program Perilaku Hidup Bersih dan Sehat (PHBS) yang bertujuan untuk meningkatkan perilaku kesehatan yang dilakukan atas kesadaran sehingga keluarga atau anggota keluarga dapat menolong dirinya sendiri di bidang kesehatan dan berperan aktif dalam kegiatan kesehatan di masyarakat, program tersebut belum fokus dalam menjelaskan kesehatan perawatan gigi dan mulut (Andriansyah, 2013; Guna \& Amatiria, 2017; Nurhajati, 2015).

Pengetahuan sebagai salah satu faktor yang mempengaruhi personal hygiene seseorang (Afriyadi \& Putri, 2018; Gayatri \& Ariwinanti, 2016; Purwanti et al., 2016). Penyebab timbulnya masalah gigi dan mulut pada masyarakat salah satunya adalah faktorperilaku dan sikap mengabaikan kebersihan gigi dan mulut (Tambunan, 2019; Wiworo, 2015). Gambaran karakteristik yaitu anak sekolah dasar usia 6-12 tahun. Hal ini dilandasi oleh kurangnya pengetahuan dan perilaku akan pentingnya pemeliharaan gigi dan mulut, kondisi anak-anak usia sekolah dasar dengan kurangnya pengetahuan dan perilaku menggosok gigi masih sangat rendah (Gayatri, 2015).

Gilang (2010) menyatakan bahwa faktorfaktor yang mempengaruhi kesehatan gigi dan mulut adalah usia, pola makan, aliran saliva dan perilaku hidup bersih dan sehat (PHBS. Munculnya berbagai penyakit yang sering menyerang anak usia sekolah (6- 10 tahun), ternyata umumnya berkaitan dengan PHBS (Kemenkes RI, 2011). Hasil penelitian menunjukkan bahwa perilaku menggosok gigi pada siswa sekolah dasar kelas V dan VI di Kecamatan Sumberejo dengan ketegori baik $54,0 \%$, lebih banyak dibandingkan dengan ketegori kurang baik 46,0\%. Perilaku yang kurang baik dalam menggosok gigi diantaranya adalah gerakan menggosok permukaan gigi rahang bawah yang menghadap ke lidah tidak benar $78,9 \%$, gerakan menggosok permukaan gigi yang menghadap ke langit-langit tidak benar $78,6 \%$, gerakan menggosok gigi untuk permukaan yang menghadap pipi tidak benar 76,5\%, lama waktu menggosok gigi yang masih kurang $64,2 \%$ dan waktu menggosok gigi yang salah $38,9 \%$ (Arianto, 2017).
Berdasarkan temuan peneliti terdapat hasil penelitian kedua variabel menunjukkan bahwa variabel pengetahuan tentang perilaku hidup bersih dan sehat berhubungan negatif (-) dengan variabel kebersihan gigi dan mulut, artinya ketika nilai variabel pengetahuan naik maka nilai variabel kebersihan gigi dan mulut akan turun. Hasil uji statistik menunjukkan terdapat hubungan antara variabel independen dengan variabel dependen. Nilai keeratan hubungan -0.747 yang artinya berada pada kisaran 0,71 - 0,90 sehingga masuk dalam kategori sangat kuat antara hubungan tingkat pengetahuan tentang perilaku hidup bersih dan sehat (PHBS) dengan kebersihan gigi dan mulut pada siswa kelas IV dan V di SDN 018 Tenggarong Seberang (Nuslan, 2018). Tujuan penelitian ini adalah untuk mengetahui hubungan hubungan perilaku hidup bersih dan sehat dengan pengetahuan dan perilaku menggosok gigi

\section{METODE PENELITIAN}

Jenis penelitian yang digunakan adalah observasional dengan pendekatan cross sectional, dimana variabel bebas dan terikat diteliti pada saat bersamaan. Populasi penelitian ini ialah seluruh siswa-siswi kelas IV SDN Sukamanah 2 Kota Tasikmalaya yang berjumlah 42 orang. Teknik pengambilan sampel dalam penelitian ini menggunakan teknik total sampling.

Pengambilan data dilakukan dengan mengisi kuesioner perilaku hidup bersih dan sehat, kuesioner pengetahuan menggosok gigi, dan lembar observasi berupa daftar ceklis perilaku menggosok gigi pada siswa-siswi kelas IV SDN Sukamanah 2 Kota Tasikmalaya. Seluruh data penelitian dibuat tabel distribusi data menggunakan excel dan seluruh data dianalisis dengan uji statistika menggunakan uji spearman correlation.

\section{HASIL DAN PEMBAHASAN}

Penelitian dilakukan di SDN Sukamanah 2 yang beralamat di Jl. Jendral Ahmad Yani Blok No.154 Kelurahan Sukamanah, Kecamatan Cipedes, Kota Tasikmalaya dengan kegiatan mengisi kuesioner PHBS, pengetahuan menggosok gigi, serta observasi perilaku menggosok gigi, diperoleh hasil sebagai berikut: 
Tabel 1. Karakteristik Responden Berdasarkan Jenis Kelamin, Umur, Pengetahuan dan Perilaku Menggosok Gigi

\begin{tabular}{|c|c|c|c|}
\hline No. & Karakteristik & $\mathrm{n}$ & $\%$ \\
\hline \multirow[t]{3}{*}{1.} & Jenis Kelamin & & \\
\hline & Laki-laki & 19 & 45,2 \\
\hline & Perempuan & 23 & 54,2 \\
\hline \multirow[t]{4}{*}{2.} & Umur & & \\
\hline & 10 tahun & 7 & 16,7 \\
\hline & 11 tahun & 32 & 76,2 \\
\hline & 12 tahun & 3 & 7,1 \\
\hline \multirow[t]{4}{*}{3.} & Umur (25 siswa) & & \\
\hline & Kurang & 8 & 14,3 \\
\hline & Baik & 25 & 59,5 \\
\hline & Cukup & 11 & 26,2 \\
\hline \multirow[t]{4}{*}{4.} & Umur (28 siswa) & & \\
\hline & Kurang & 1 & 2,4 \\
\hline & Baik & 13 & 31,0 \\
\hline & Cukup & 28 & 66,7 \\
\hline \multirow[t]{4}{*}{5.} & Umur (34 siswa) & & \\
\hline & Kurang & 6 & 14,3 \\
\hline & Baik & 34 & 81,0 \\
\hline & Cukup & 2 & 4,8 \\
\hline
\end{tabular}

Berdasarkan tabel 1 menunjukkan responden yang paling banyak pada penelitian ini yaitu umur 11 sebanyak 32 siswa $(76,2 \%)$.

Tabel 2. Hasil Analisis Data Menggunakan Uji Korelasi Spearman pada Pengetahuan PHBS dengan Pengetahuan Menggosok Gigi

\begin{tabular}{lccc}
\hline Variabel & $\begin{array}{c}\text { Rata- } \\
\text { rata }\end{array}$ & p-Value & $\begin{array}{c}\text { Correlation } \\
\text { Coeficient }\end{array}$ \\
\hline Pengetahuan PBS & 2,12 & 0,000 & 0,534 \\
Pengetahuan & 2,64 & & \\
Menggosok Gigi & & & \\
\hline
\end{tabular}

Berdasarkan Tabel 2 menunjukkan hasil analisis data menggunakan uji korelasi spearman dimana terdapat hubungan pada variabel pengetahuan PHBS yang dihubungkan dengan pengetahuan menggosok gigi, hal ini di dapatkan nilai $\mathrm{p}$ value $0,000<0,05$ dan hasil correlation coeficient sebesar 0,534 dapat disimpulkan bahwa korelasi antara kedua variabel ini kuat.
Tabel 3. Hasil Analisis Data Menggunakan Uji Korelasi Spearman pada Pengetahuan PHBS dengan Perilaku Menggosok Gigi

\begin{tabular}{cccc}
\hline Variabel & $\begin{array}{c}\text { Rata- } \\
\text { rata }\end{array}$ & $\begin{array}{c}\mathrm{p}- \\
\text { Value }\end{array}$ & $\begin{array}{c}\text { Correlation } \\
\text { Coeficient }\end{array}$ \\
\hline $\begin{array}{c}\text { Pengetahuan } \\
\text { PHBS }\end{array}$ & 2,12 & 0,002 & 0,471 \\
\hline
\end{tabular}

Berdasarkan tabel 3 menujukkan hasil analisis data menggunakan uji korelasi spearman terdapat hubungan antara kedua variabel, hal ini didapatkan nilai $\mathrm{p}$ value $0,002<0,05$ dan hasil correlation coefisiente 0,471 bahwa kedua korelasi antara kedua variabel ini cukup.

Berdasarkan hasil penelitian yang dilaksanakan pada tanggal 22 Februari 2020 tentang hubungan Perilaku Hidup Bersih dan Sehat (PHBS) dengan pengetahuan dan perilaku menggosok gigi pada siswa kelas IV SDN Sukamanah 2 Kota Tasikmalaya diperoleh hasil penelitian responden yang terdiri dari jenis kelamin laki-laki sebanyak 19 siswa $(45,2 \%)$ dan perempuan sebanyak 23 siswa $(54,7 \%)$. Responden paling banyak yaitu pada umur 11 tahun sebanyak 32 siswa $(76,1 \%)$. Responden dengan pengetahuan menggosok gigi kurang sebanyak 1 siswa $(2,4 \%)$, cukup sebanyak 13 siswa $(31,0 \%)$, dan baik sebanyak 23 siswa $(66,7 \%)$.

Hasil uji statistik Spearman diperoleh p-value $0,000<0,05$ sehingga dapat di katakan ada hubungan penerapan perilaku hidup bersih dan sehat (PHBS) dengan pengetahuan menggosok gigi serta korelasi antara kedua variabel ini kuat dengan nilai 0,534 yaitu korelasi kuat, ini menunjukkan bahwa responden menerapkan perilaku hidup bersih dan sehat (PHBS) yang sudah diterapkan di sekolah serta didapatkan nilai tertinggi pada pengetahuan menggosok gigi yaitu kategori baik sebanyak 28 siswa atau 66,7\% sedangkan pada perilaku menggosok gigi dapatkan nilai tertinggi yaitu pada kategori cukup sebanyak 34 siswa atau $81,0 \%$. Hal ini menunjukkan bahwa setiap pengetahuan kadang tidak sesuai dengan perilakunya, seseorang tahu dengan apa yang ada dalam pikirannya tetapi kadang seseorang pun tidak bisa mempraktikan melauli perilaku atau tindakannya (Afriyadi \& Putri, 2018; Gayatri \& Ariwinanti, 2016; Tambunan, 2019). 
Responden dengan perilaku menggosok gigi kurang sebanyak 6 siswa $(14,3 \%)$, cukup sebanyak 34 siswa $(81,0 \%)$, dan baik sebanyak 2 siswa $(4,8 \%)$. Hasil uji statistik spearman diperoleh $\mathrm{p}$-value $0,002<0,05$ sehingga dapat dikatakan ada hubungan Perilaku Hidup bersih dan sehat (PHBS) dengan Perilaku menggosok gigi serta kolerasi antara kedua variabel yaitu cukup yaitu 0,471. Sejalan dengan penelitian Nuslan, (2018) bahwa siswa usia sekolah membutuhkan pengetahuan tentang PHBS karena munculnya penyakit pada anak usia sekolah umumnya berkaitan dengan PHBS. Perilaku muncul dari pengetahuan oleh karena itu penting bagi siswa memiliki pengetahuan yang baik tentang PHBS, guru diminta oleh pihak sekolah untuk menyelipkan materi tentang kesehatan terutama materi yang berkaitan hidup bersih dan sehat. Penelitian ini juga sejalan dengan penelitian Arianto (2017) yang menunjukkan bahwa perilaku menggosok gigi pada siswa sekolah dasar kelas V dan VI di Kecamatan Sumberejo dengan kategori baik 54,0\%, lebih banyak dibandingkan dengan kategori kurang baik $46,0 \%$. Perilaku yang kurang baik dalam menggosok gigi diantaranya adalah gerakan menggosok permukaan gigi rahang bawah yang menghadap ke lidah tidak benar $78,9 \%$, gerakan menggosok permukaan gigi yang menghadap ke langit-langit tidak benar 78,6\%, gerakan menggosok gigi untuk permukaan yang menghadap pipi tidak benar $76,5 \%$, lama waktu menggosok gigi yang masih kurang $64,2 \%$ dan waktu menggosok gigi yang salah $38,9 \%$. Perilaku menggosok gigi pada siswa juga terkait dengan fasilitas, sarana dan prasarana yang mendukung.

Adapun sarana dan prasarana yang harus tersedia adalah sikat gigi yang dimiliki milik siswa sendiri, pasta gigi yang berfluor, air bersih, tempat untuk berkumur. Pengetahuan dan sikap saja belum menjamin terjadinya perilaku, maka masih diperlukan sarana yang mendukung perilaku tersebut (Tambunan, 2019; Wiworo, 2015).

\section{KESIMPULAN DAN SARAN}

Kesimpulan dalam penelitian ini adalah perilaku hidup bersih dan sehat siswa kelas IV SDN Sukamanah 2 Kota Tasikmalayan sebagian besar baik (66,7\%). Pengetahuan menggosok gigi sebagian besar cukup $(59,5 \%)$ dan perilaku menggosok gigi sebagian besar kategori baik $(66,7 \%)$. Terdapat hubungan antara pengetahuan PHBS dengan pengetahuan dan perilaku menggosok gigi.

Saran dari penelitian ini perlu adanya penelitian lanjutan mengenai hubungan PHBS dengan variabel lain di luar yang diteliti oleh peneliti

\section{REFERENSI}

Afriyadi, S., \& Putri, M. E. (2018). Hubungan Personal Hygiene Dan Perilaku Menjaga Kebersihan Lingkungan Sekolah Dengan Kejadian Ascariasis Di Sdn 04/Iv Arab Melayu Kec. Pelayangan Kota Jambi. Jurnal Akademika Baiturrahim Jambi, 5(1), 59-71.

Andriansyah, Y. (2013). Penyuluhan Dan Praktik PHBS (Perilaku Hidup Bersih Sehat) Dalam mewujudkan masyarakat Desa Peduli Sehat. Asian Journal of Innovation and Entrepreneurship, 2(01), 45-50.

Agusta,M,V. Ismail,A.K.\&Firdausy,D.M., (2014). Hubungan Pengetahuan Kesehatan Gigi dan Mulut dengan kondisi Oral Hygiene Anak Tuna Rungu Usia Sekolah. Program Pendidikan Dokter Gigi Fakultas Kedokteran Gigi Universitas Islam Sultan Agung,Staff Pengajar Fakultas Kedokteran Gigi Universitas Islam Sultan Agung. Diakses (23 November 2019).

Arianto., Shaluhiyah Z.,Nugraha P. (2017). Perilaku Menggosok Gigi pada Siswa Sekolah Dasar Kelas V dan VI di Kecamatan Sumberejo. Jurnal Promosi Kesehatan Indonesia Vol. 9 / No. 2 / Agustus 2017. Diakses pada tanggal (18 November 2019).

Budiman dan Riyanto., (2013), kuesioner pengetahuan dan sikap dalam penelitian Kesehatan. Jakarta: Salemba Medika.

Depkes, RI,(2009). indeks pembangunan Indonesia (IPM) Direktorat Jendral Pelayanan Medika, Jakarta. 6. Diyantini, N.K,dkk., (2015). Hubungan Karakteristik dan kepribadian anak dengan kejadian bullying pada siswa kelas $\mathrm{V}$ di SD "X" di Kabupaten Bandung. Jurnal Fakultas Kedokteran. Universitas Undayana.

Gayatri, R. W., \& Ariwinanti, D. (2016). Tingkat Pengetahuan Kesehatan Gigi Anak Sekolah Dasar Negeri Kauman 2 Malang. Preventia: 
The Indonesian Journal of Public Health, l(2), 186-190.

Gayatri, Rara Warih., (2015). Gambaran Karies gigi anak usia sekolah dasar di Kota Malang. Journal Preventia Vol 1 No 1 Juni 2015 hal 4250.. Malang: UM Press

Gilang, A. R. (2010). Serba Serbi Kesehatan Gigi dan Mulut. Jakarta: Agromedia Pustaka.

Guna, A. M., \& Amatiria, G. (2017). Perilaku hidup bersih dan sehat (PHBS) dalam upaya mencegah penyakit kulit pada santri di pondok pesantren Nurul Huda. Jurnal Ilmiah Keperawatan Sai Betik, 11(1), 7-14.

Hidayat, R., Tandiari, A., (2016). Kesehatan Gigi Dan Mulut-Apa Yang Sebenarnya Anda Tahu?. Yogyakarta: CV ANDI OFFSET.

Kemenkes RI., (2011). Pedoman Pembinaan Perilaku Hidup Bersih DanSehat (PHBS). Jakarta: Direktorat Promosi Kesehatan Kementrian Kesehatan RI.

(2016). Direktorat Promosi Kesehatan dan Pemberdayaan Masyarskat. Jakarta: Direktorat Promosi Kesehatan Kementrian Kesehatan RI.

Kementerian Pendidikan Dan Kebudayaan .(2020). Data Pokok Pendidikan Dasar danMenengah. https://dapo.dikdasmen.kemdikbud.go.id/seko lah/43E697DF952D7A06DD03 diakses pada tanggal (11 Juli 2020).
Kholid, A., (2014). Promosi Kesehatan di dengan pendekatan teori perilaku, media, dan aplikasinya. Jakarta: PT.Rajagrafindo Persana.

(2012). Promosi Kesehatan Di Pusksmas.Jakarta: PT. Rajagrafindo Persana.

Nuslan, M., (2018). Hubungan Tingkat Pengetahuan Tentang Perilaku Hidup Bersih Dan Sehat (PHBS) Dengan Kebersihan Gigi Dan Mulut Pada Siswa Kelas IV Dan V Di SDN 018 Tenggarong Seberang. Skripsi: Universitas Muhamaddiyah Kalimantan Timur

Nurhajati, N. (2015). Perilaku Hidup Bersih dan Sehat (PHBS) Masyarakat Desa Samir Dalam Meningkatkan Kesehatan Masyarakat. Jurnal Publiciana, 8(1), 107-126.

Purwanti, N., Jirna, I. N., \& Arjani, I. (2016). Analisis Hubungan Kadar Gula Darah Puasa dengan Kadar Kolesterol High Density Lipoprotein (HDL) pada Pasien Diabetes Mellitus Tipe 2 di RSUP Sanglah. Meditory, 4(1), 65-72.

TAMBUNAN, N. J. (2019). Gambaran Pengetahuan Ibu Tentang Cara Menyikat Gigi Terhadap Kebersihan Gigi Dan Mulut Pada Siswa/Siswi Kelas IV \& V SD Negeri NO. 173547 Tambunan Kecamatan Balige Kabupaten Toba Samosir.

Wiworo, H. (2015). Sikap Pelihara Diri Gigi dan Mulut Sebagai Upaya Pencegahan Dini Terjadinya Karies Gigi Anak. Buletin Warta Kampus, 10, 26-27. 